\title{
Chapter 10 \\ Why Do the Radionuclide Concentrations of Pacific Cod Depend on the Body Size?
}

\author{
Yoji Narimatsu, Tadahiro Sohtome, Manabu Yamada, Yuya Shigenobu, \\ Yutaka Kurita, Tsutomu Hattori, and Ryo Inagawa
}

\begin{abstract}
We examined year-class-related differences in radiocesium concentrations in Pacific cod (Gadus macrocephalus) and evaluated the potential factors affecting the differences after the release of large amounts of radionuclides from Fukushima Dai-ichi Nuclear Power Plant (FNPP) in March 2011. The concentration of radiocesium was highest in the 2009 and earlier year-classes (yc) $(\leq 2009 \mathrm{yc})$, followed by the $2010 \mathrm{yc}$, and was rarely detected in the $2011 \mathrm{yc}$. Trawl surveys throughout the year revealed that a proportion of Pacific cod born in or before 2009 and 2010 were distributed in the coastal area from winter to early summer, whereas all individuals were on the upper continental slope from early summer to winter. The concentration of radiocesium decreased more rapidly in the $2010 \mathrm{yc}$ than in the $\leq 2009$ yc. The diet of cod changed ontogenetically and spatiotemporally. The organisms preyed upon on the upper continental slope by cod of all year-classes and in the coastal area by the $2010 \mathrm{yc}$ contained very low concentrations of radiocesium. However, some food items ingested in the coastal area by the $\leq 2009$ yc had relatively
\end{abstract}

\footnotetext{
Y. Narimatsu $(\bowtie) \cdot T$. Hattori

Hachinohe Laboratory, Tohoku National Fisheries Research Institute, Fisheries Research Agency, 25-259, Shimomekurakubo, Samemachi, Hachinohe, Aomori 031-0841, Japan e-mail: nary@affrc.go.jp

T. Sohtome $\bullet$ M. Yamada

Fukushima Prefectural Fisheries Experimental Station,

13-2, Matsushita, Onahamashimokajiro, Iwaki, Fukushima 970-0316, Japan

Y. Shigenobu

National Research Institute of Fisheries Sciences, Fisheries Research Agency,

2-12-4, Fukuura, Kanazawa, Yokohama, Kanagawa 236-8648, Japan

Y. Kurita

Tohoku National Fisheries Research Institute, Fisheries Research Agency,

3-27-5, Shinhama-cho, Shiogama-city, Miyagi, 985-0001, Japan

R. Inagawa

Hachinohe Laboratory, Tohoku National Fisheries Research Institute, Fisheries Research Agency, 25-259, Shimomekurakubo, Samemachi, Hachinohe, Aomori 031-0841, Japan

Kushiro Laboratory, Hokkaido National Fisheries Research Institute, Fisheries Research Agency, 116 Katsurakoi, Kushiro, Hokkaido 085-0802, Japan
} 
high radiocesium levels. These results suggest that Pacific cod primarily accumulated radiocesium during the first few months after the FNPP accident. Age- and body size-dependent differences in growth, metabolic rate, and diet, as well as seasonal migration patterns, also affected the rate of decrease in radiocesium levels, which likely led to the differences we observed between year-classes.

Keywords Pacific cod $\bullet$ Nuclear Power Plant accident $•$ Radiocesium $\bullet$ Year-class

- Seasonal migration $\bullet$ Ontogenetic shift of diet

\subsection{Introduction}

Huge amounts of radionuclides were released from the devastated Fukushima Daiichi Nuclear Power Plant following the Great East Japan Earthquake on 11 March 2011. The radionuclides contaminated the air, land, and ocean both directly and indirectly. Model estimates suggest that $3.5 \pm 0.7 \mathrm{PBq}$ radiocesium 137 was emitted directly to the ocean (Tsumune et al. 2012). A number of marine organisms ingested radionuclides into their body via the water and their diet. As a result, high concentrations of radiocesium were detected in almost all fish that inhabit the coast of Fukushima Prefecture within a year after the tsunami (Buesseler 2012). The level of contamination has decreased over time, and has now stabilized at a low level in pelagic fish species and invertebrates (Wada et al. 2013; Sohtome et al. 2014). In contrast, the decline in radionuclide levels has occurred more slowly in demersal fishes, resulting in food safety problems.

Pacific cod (Gadus macrocephalus) are one of the most important species in the upper continental slope ecosystem for commercial fishermen in the North Pacific off northern Japan (Tohoku area). The concentration of radiocesium in demersal fishes such as bighand thornyhead (Sebastolobus macrochir) and threadfin hakeling (Laemonema longipes) that inhabit the upper continental slope was low and stable even soon after the Fukushima Daiichi Power Plant (FNPP) accident (MAFF 2014). Despite occupying a similar spatial niche as these species, the radiocesium levels in some Pacific cod individuals were higher than allowable values in Japan $\left({ }^{134} \mathrm{Cs}+{ }^{137} \mathrm{Cs}\right.$, $100 \mathrm{~Bq} / \mathrm{kg}$-wet). Additionally, the majority of demersal fishes that had radiocesium levels exceeding this standard were clustered in Fukushima and neighboring prefectures. In contrast, unsafe levels of radiocesium were measured in Pacific cod over a much wider area in 2011 and 2012, including five prefectures in the Tohoku district.

Commercial fishing or landing of cod was prohibited for 8 months after the shipment of cod was regulated in May 2012 in Miyagi Prefecture. The cod fishery was partially restarted in September 2012 when small cod $(<1 \mathrm{~kg})$ were approved for harvest, because high levels of radiocesium were only detected in large fish $(\geq 1 \mathrm{~kg}$ ). Therefore, the concentration of radiocesium in Pacific cod appears to be a 
function of age and body length. Our objective was to evaluate the relationship between age, body size, and radiocesium concentrations in Pacific cod following the FNPP accident. We documented the seasonal change in the distribution of fish of two age classes. Additionally, we evaluated the feeding ecology of Pacific cod in two regions to document ontogenetic shifts in diet. We measured radiocesium concentrations in the primary diet items of Pacific cod. Based on these data, we estimated when and how radiocesium was taken up by Pacific cod and the rate of decrease. We then used these results to predict conditions in the near future.

\subsection{Radiocesium Concentration of Pacific Cod}

We recorded the standard length and body weight of Pacific cod that were captured from April 2011 to March 2014 off Fukushima Prefecture and then removed the sagittal otoliths. One of the sagittal otoliths was cut into slices with hard resin and used for age determination following the method of Hattori et al. (1992). We determined the birth year-class of all specimens. Muscle tissue samples were removed from the vertebrae and skin to measure radiocesium concentrations. We examined the temporal changes in radiocesium concentration following the nuclear accident and compared the levels among year-classes (ycs).

The radiocesium concentration of Pacific cod was always higher in the year classes of 2009 and earlier ( $\leq 2009$ yc) than in the 2010 yc (Fig. 10.1). The radiocesium concentrations measured from April 2012 to March 2013 ranged from

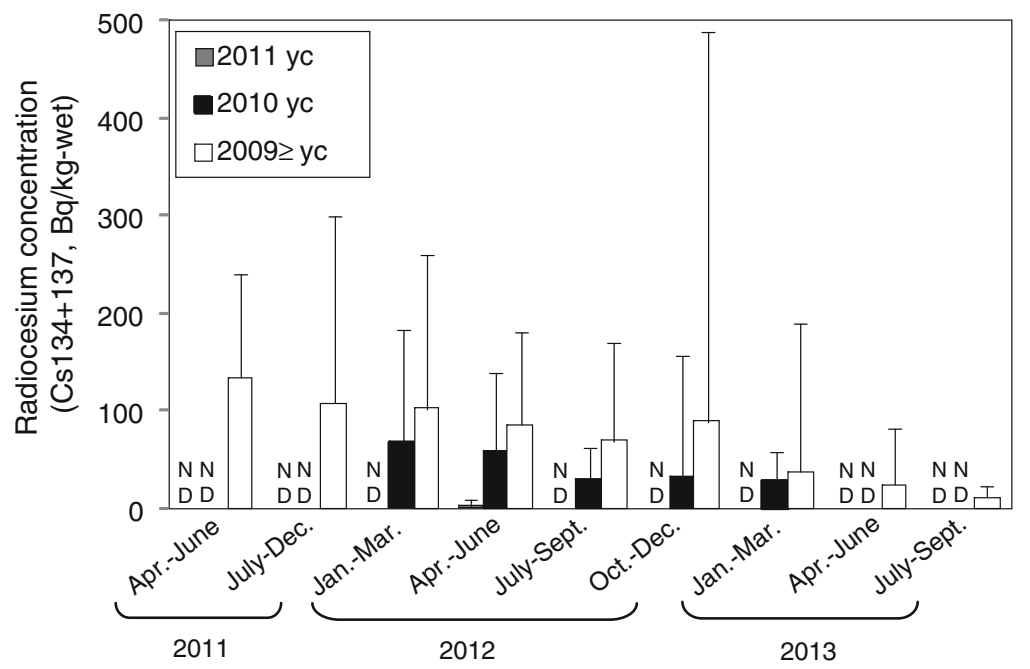

Fig. 10.1 Temporal changes in radiocesium $\left({ }^{134} \mathrm{Cs}+{ }^{137} \mathrm{Cs}\right)$ concentration in the 2011, 2010, and $\leq 2009$ year-classes of Pacific cod. Boxes and bars represent the average and maximum values, respectively. $N D$ no data 


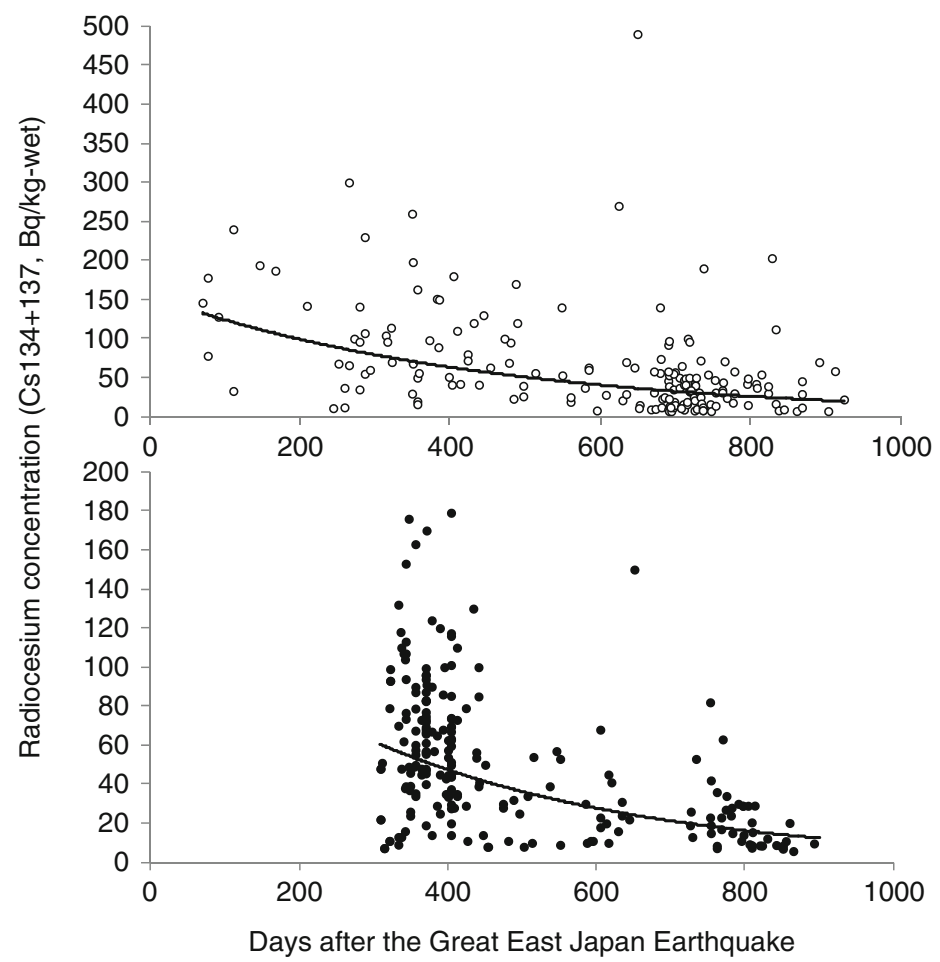

Fig. 10.2 Decay process of radiocesium in $\leq 2009$ (upper) and 2010 (lower) year-classes of Pacific cod. The relationships were fitted for exponential function, expressed by the curved lines

0.37 to 0.75 times (average $\pm \mathrm{SD}=0.57 \pm 0.16$ ) lower in the $2010 \mathrm{yc}$ than in the year-classes from 2009 and earlier. The concentration of radiocesium has decreased temporally since the nuclear plant accidents in both year-classes (Fig. 10.1). Interestingly, radiocesium was rarely detected, or detected at very low levels, in the $2011 \mathrm{yc}$.

The ecological half-life (Morita and Yoshida 2005; Iwata et al. 2013) was calculated using the exponential regression for surveyed concentrations of radiocesium and used to estimate the half-lives of radiocesium. This value can be used to predict future radiocesium concentrations. The regressions suggest that the ecological halftime of radiocesium was 309 and 258 days in the $\leq 2009$ and 2010 year classes, respectively (Fig. 10.2). These results suggest that older and larger individuals concentrated higher levels of radiocesium and/or excreted radiocesium at a slower rate than younger and smaller Pacific cod individuals. The factors affecting age-related difference are examined in the subsequent sections. 


\subsection{Seasonal Change in Distribution}

We conducted benthic trawl surveys from 2004 to 2013 in the northern Pacific off Honshu Island, Japan (Tohoku area) and in Sendai Bay using two research vessels (Table 10.1). Surveys off Tohoku area were conducted in April and in OctoberNovember at depths between 150 and 900 m (Fig. 10.3, Table 10.1). Surveys in Sendai Bay were conducted in January, February, April, June, July, and November at depths between 30 and $122 \mathrm{~m}$. The details of the benthic trawl survey

Table 10.1 List of trawl survey cruises conducted in the present study by the research vessels Dai-nana Kaiyo-maru (D), or Wakataka-maru (W) in Sendai Bay (S) or offshore of Tohoku (T) giving the duration of the survey and number of benthic trawl tows $(N)$

\begin{tabular}{l|l|l|l|r}
\hline Cruise & Vessel & Area & Duration & $N$ \\
\hline 200407 & W & S & 28 Jun-2 Jul 2004 & 12 \\
\hline 201006 & W & S & 20-23 Jun 2010 & 12 \\
\hline 201202 & D & S & 2-6 Feb 2012 & 6 \\
\hline 201204 & W & S\&T & 17-25 Feb 2012 & 19 \\
\hline 201210 & W & S\&T & 20 Oct-21 Nov 2012 & 31 \\
\hline 201304 & W & S\&T & 16-23 Apr 2013 & 20 \\
\hline 201310 & W & S\&T & 15 Oct-25 Nov 2013 & 38 \\
\hline
\end{tabular}

Fig. 10.3 Location of the study site and the epicenter of the Great East Japan Earthquake. Surveys were conducted at depths of $38-650 \mathrm{~m}$ in Sendai Bay and offshore of Tohoku

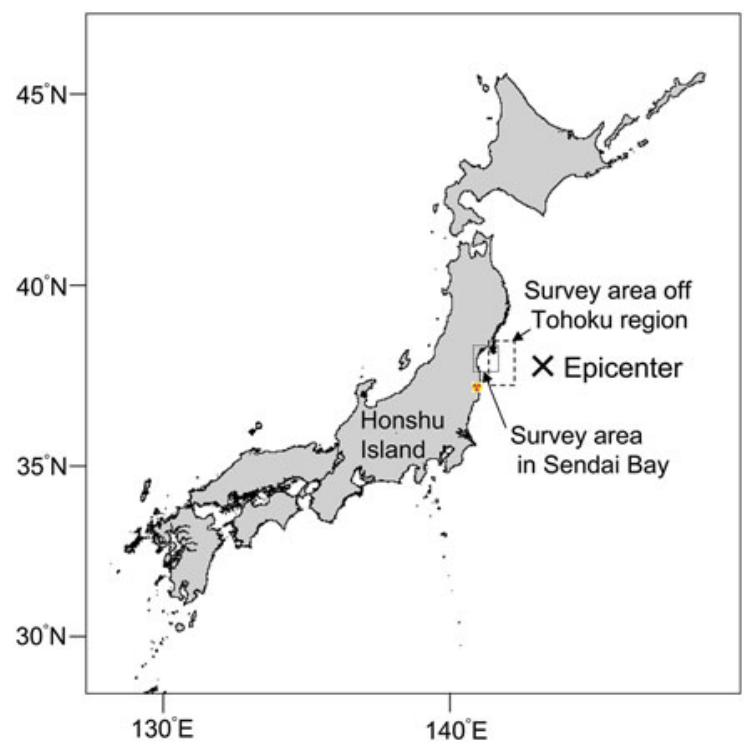



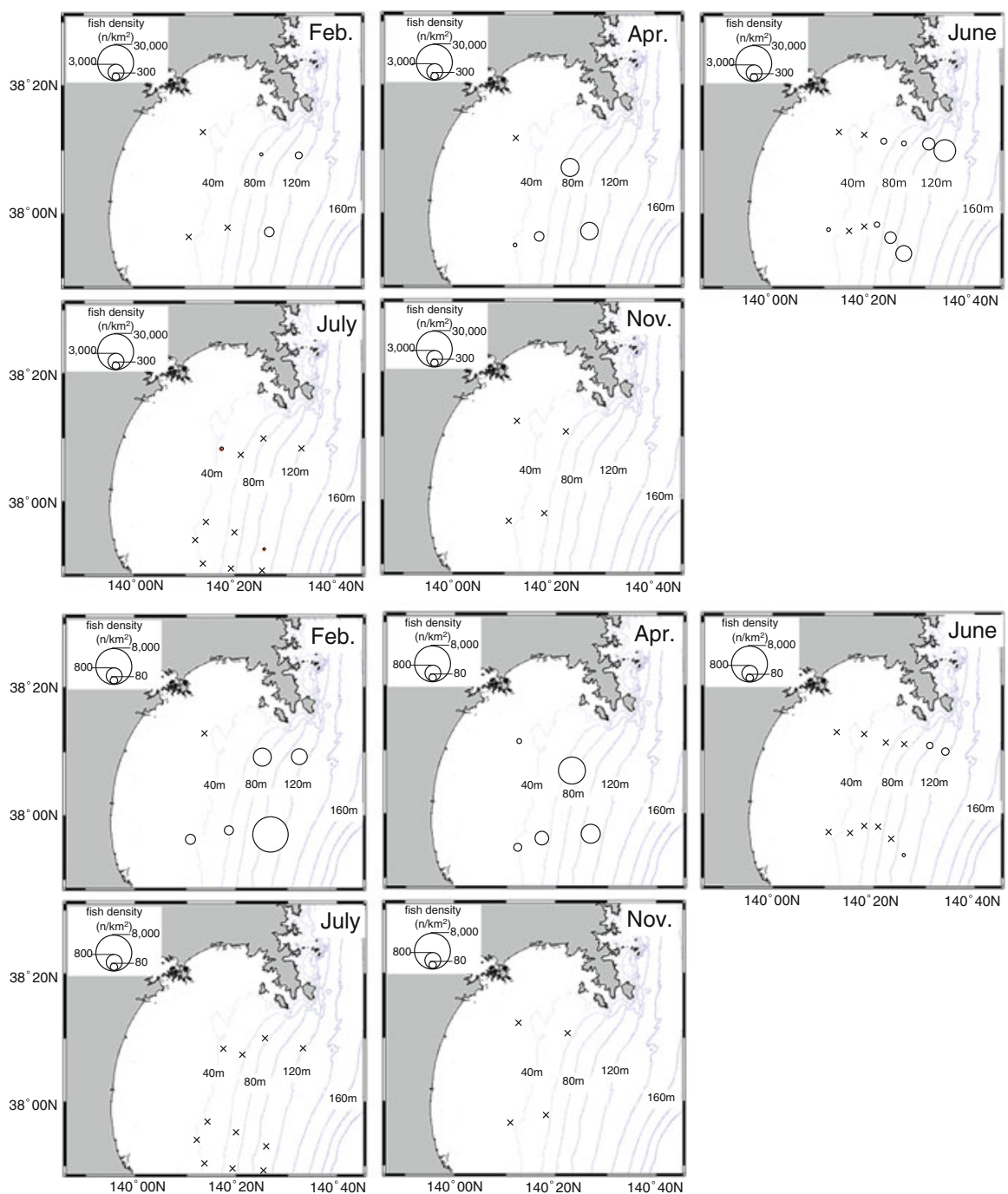

Fig. 10.4 Seasonal changes in the distribution of age $1+$ (upper) and age $\geq 2+$ (lower) Pacific cod in and off Sendai Bay. The timing of the surveys is described in Table 10.1

methodology are described by Hattori et al. (2008). We counted the number of age $1+$ and 2+ Pacific cod caught in the net and estimated fish density (numbers $/ \mathrm{km}^{2}$ ) by dividing the number of fish captured by the trawl area.

Pacific cod aged 1+ year old were captured in shallow areas in Sendai Bay from February to June, but not in July and November (Fig. 10.4). In February and June, the majority of age $1+\operatorname{cod}$ were captured at depths $>80 \mathrm{~m}$, whereas in April they 
were captured in shallower waters. Pacific cod of age $\geq 2+$ were also captured in Sendai Bay from February to June, with peak catches occurring in February and April. Only a few individuals remained in the Bay in June, and none was captured in the area shallower than $120 \mathrm{~m}$ in July and November.

Based on the results of this long-term trawl survey, Pacific cod appear to be widely distributed offshore of Tohoku in the spring and autumn (Fig. 10.5). In April, 1+-year-old Pacific cod tend to occupy the 100 to $400 \mathrm{~m}$ depth zone off Tohoku, but the density is highest at 100-200 $\mathrm{m}$ and very low at $\geq 300 \mathrm{~m}$. In OctoberNovember, age 1+ cod occupied the depth zone from 200 to $500 \mathrm{~m}$, with density peaking at 200-400 m. Cod were not captured in areas shallower than $200 \mathrm{~m}$ during these months. Age $\geq 2+$ cod were captured at depths of $100-600 \mathrm{~m}$ and 200-600 m in April and October, respectively. The distribution of Pacific cod differed between months. The cod occupied depths that are about $100 \mathrm{~m}$ shallower in April (300$400 \mathrm{~m}$ ) than in October.

The density of fish was compared between Sendai Bay and Tohoku for samples collected in April and in October-November. The density of 1+-year-old individuals was high at depths of 50-200 m, and particularly at 80-150 m (Fig. 10.5). Fish were seldom captured deeper than $300 \mathrm{~m}$. The density of age 1+ Pacific cod was about four times higher at the 38-100 m depth than at 120-450 $\mathrm{m}$ in April. The age $\geq 2+$ individuals were widely distributed, from 50 to $500 \mathrm{~m}$. In contrast, in autumn, Pacific cod of both age classes were distributed from 200 to $600 \mathrm{~m}$, but were most

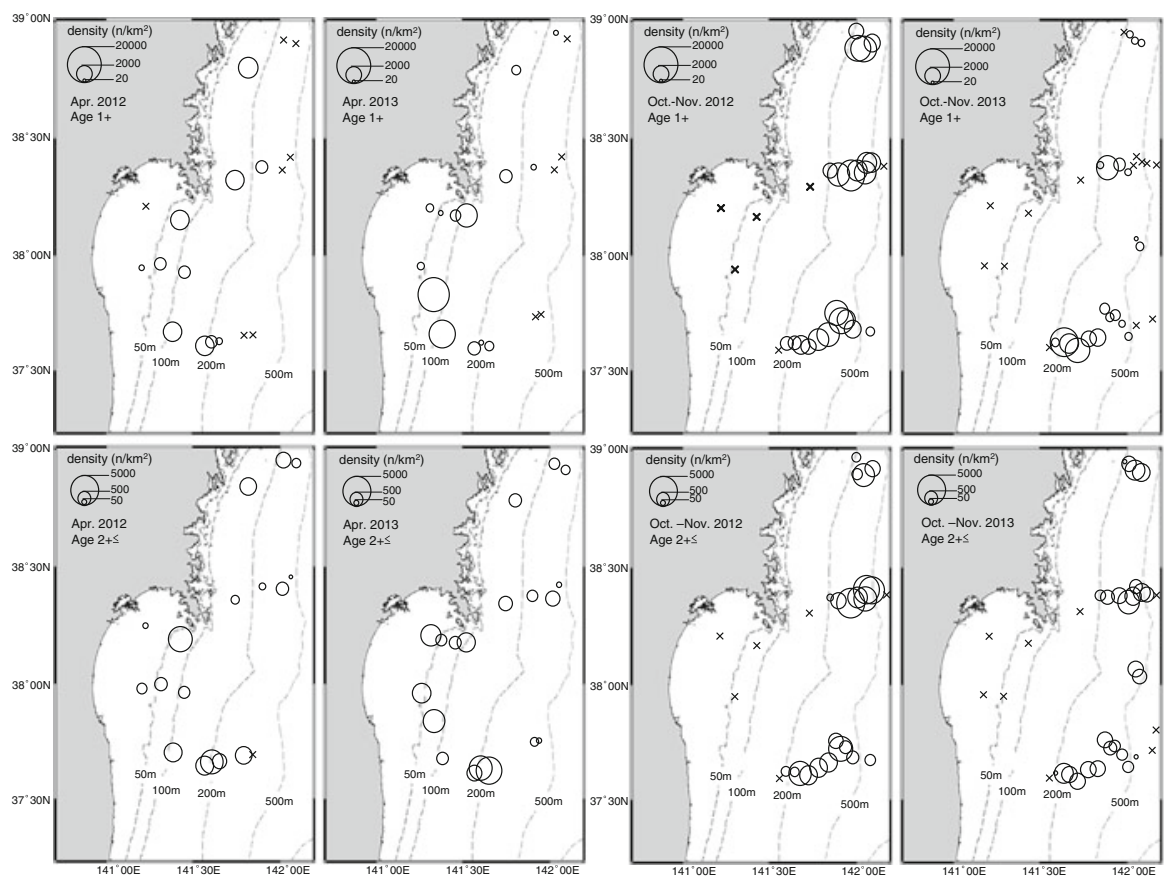

Fig. 10.5 Comparison of the distribution of age 1+ (upper) and age $\geq 2+$ (lower) Pacific cod between spring and autumn. The timing of the surveys is described in Table 10.1 
abundant at 200 to $500 \mathrm{~m}$. The density of age $\geq 2+$ Pacific cod was about two times higher at 38-100 $\mathrm{m}$ than at $120-450 \mathrm{~m}$ in April. These observations suggest that Pacific cod could inhabit the area near the FNPP at high density in April, during the time when cold water flows into Sendai Bay and offshore areas (Ito et al. 2004), but these fish migrate to the continental slope in July and remain there for several months.

Trawl surveys conducted off Tohoku throughout the year revealed that age 1+ and older Pacific cod were distributed at depths of 200-600 $\mathrm{m}$ in autumn, consistent with a previous report (Kitagawa et al. 2002), indicating that Pacific cod only inhabit the upper-continental slope during the autumn. In contrast, Pacific cod were distributed over both the upper continental slope and the continental shelf from winter to early summer. In Sendai Bay, age $1+$ and $\geq 2+$ individuals were represented in the catch from February to June. The older cod migrated into Sendai Bay and moved offshore slightly earlier than the younger individuals. In April, Pacific cod aged 1+ and $\geq 2+$ years old were distributed throughout Sendai Bay, and their density was highest at the bay mouth (80-200 m deep). A large amount of radiocesium was released into the ocean after the FNPP accident in mid-March 2011, at a time when Pacific cod had likely moved into the shallower area. After occupying this area for a maximum of 3 or 4 months, the cod migrated off the continental shelf in July and did not return to the bay until February of the next year. Cod were distributed at depths similar to those of bighand thornyhead, Sebastolobus macrochir (Hattori et al. 2008), and threadfin hakeling, Laemonema longipes (Narimatsu et al. 2014), in offshore areas. The concentration of radiocesium in these two species remained very low or was nondetectable (Wada et al. 2013; MAFF 2014). Taking into consideration the pattern of seasonal migration, the rate of decline of radiocesium levels in Pacific cod, and the concentration of radiocesium in other species that occupy the upper continental slope, we conclude that contamination of Pacific cod with radiocesium occurred soon after the nuclear plant accident, from March to June in 2011.

\subsection{Ontogenetic and Seasonal Diet Shift of Pacific Cod}

Age 1+ and 2+ Pacific cod caught in Sendai Bay and off the Tohoku area, which is located off FNPP with a depth of $250 \mathrm{~m}$, were used to evaluate their diet. Samples of fish were collected in April, June, and November in Sendai Bay, and in April and November off Tohoku. Fish were frozen soon after capture, their standard length and body weight were recorded, and they were dissected in the laboratory. The stomach was cut open and food items were sorted to the lowest possible taxon. Prey items were weighed to nearest $1 \mathrm{mg}$ (wet weight). The percent contribution of each prey item to the diet of each age class was calculated. We compared the seasonal and spatial variation and ontogenetic shifts in the diet of Pacific cod.

A total of 247 fish stomachs were examined yielding 36 taxon or species of prey items. The primary prey items ( $>1 \%$ of the total wet weight) differed among seasons, habitat types, and the body size of cod. In Sendai Bay, age 1+ Pacific cod 


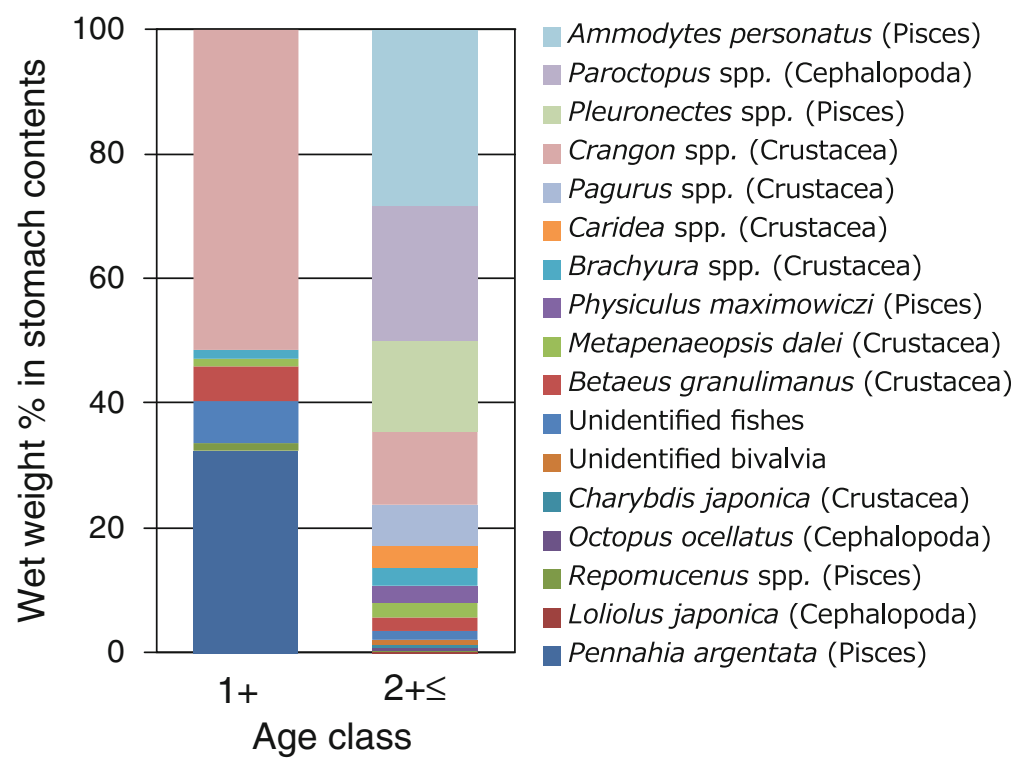

Fig. 10.6 Ontogenetic shift in diet for Pacific cod in Sendai Bay from April to June in 2012 and 2013

preyed primarily on Crangon spp. (Crustacea) such as Crangon affinis and C. dalli, followed by white croaker (Pennahia argentata, Pisces; Fig. 10.6). These two prey items accounted for $84 \%$ of the total diet. Unidentified Pisces (6.9\%) and Betaeus granulimanus (Decapoda) were the next most common prey items. Age $\geq 2+$ Pacific cod consumed a wider range of organisms compared with younger fish. In Sendai Bay, the older cod most commonly preyed on sand lance (Ammodytes personatus), followed by Paroctopus spp. (P. dofleini and P. conispadiceus), Pleuronectes spp. (P. herzensteini and P. yokohamae), and Crangon spp. A number of other fish and invertebrates were observed in the stomachs of age 2+ Pacific cod captured from April to June in Sendai Bay.

Age 1+ Pacific cod fed on the small pelagic invertebrates Euphausia pacifica, Watasenia scintillans, and Themisto japonica in April and June on the upper continental slope off Tohoku (Fig. 10.7). Age $\geq 2+$ Pacific cod preyed primarily on flathead flounder Hippoglossoids dubius, followed by Euphausia pacifica. In October and November, benthic shrimp Pandalus eous were the most abundant (wet-weight) prey item of 1-year-old Pacific cod, followed by myctophid fish Diaphus watasei and unidentified fishes (Fig. 10.7). Older cod frequently fed on unidentifiable fishes, as well as Diaphus watasei and horsehair crab Erimacrus isenbeckii. These observations suggest that Pacific cod shift food items not only ontogenetically but also spatiotemporally.

Age 1+ cod fed on benthic Natantia euphausiids, small decapod cephalopods, small fishes, and cephalopod octopi whereas age $\geq 2+$ individuals fed on Cephalopoda 


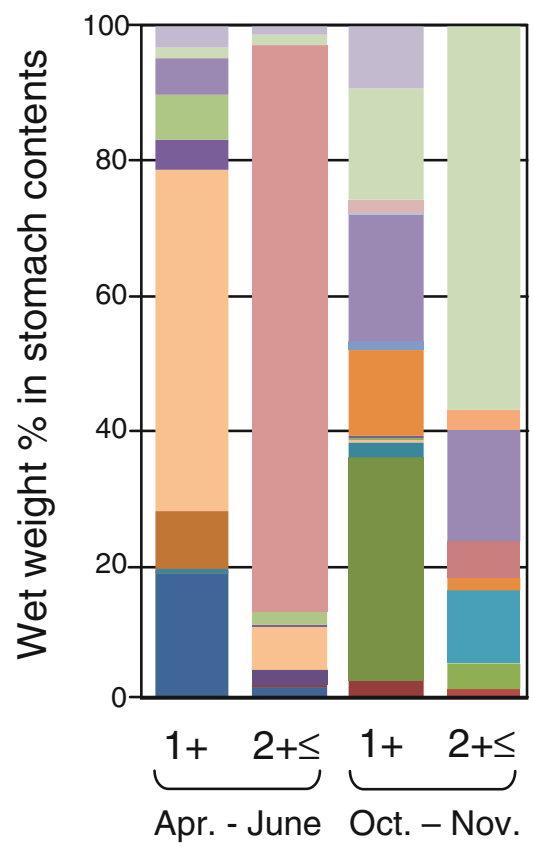

Unidentified

Unidentified fishes

Cottiusculus schmidti (Pisces)

Maurolicus japonicus (Pisces)

Bregmaceros japonicus (Pisces)

Hippoglossoides dubius (Pisces)

Diaphus watasei (Cephalopoda)

Engraulis japonicus

Ophiuroids spp. (Ophiuroidea)

Unidentified crustacea

Brachyura spp. (Crustacea)

Erimacrus isenbeckii (Crustacea)

Caridea spp. (Crustacea)

Pandalus eous Crustacea)

Crangon spp. (Crustacea)

Euphausia pacifica (Crustacea)

Themisto japonica (Crustacea)

Gammaridea spp. (Crustacea)

Polynoidea spp. (Polychaeta)

Paroctopus spp. (Cephalopoda)

Unidentified squids

Watasenia scintillans (Crustacea)

Fig. 10.7 Ontogenetic and temporal changes in diet for Pacific cod off Tohoku from October to November in 2012 and 2013

(octopods), benthic Natantia, Brachyura, and fish, including flatfish. Prior studies have documented a diet shift in Pacific cod distributed in areas deeper than $100 \mathrm{~m}$ (Hashimoto 1974; Yamamura 1994; Fujita et al. 1995). Cod smaller than $30 \mathrm{~cm}$ SL (corresponding to 1+-year-old individuals) primarily consume planktonic organisms. Cod in the range 30-40 cm SL (1+ to 2+ years old) also depend on Euphausiids, but the contribution to their diet is lower than for $30 \mathrm{~cm}$ fish, and they also feed on demersal organisms. Fish larger than $40 \mathrm{~cm}$ SL ( $\geq 2+$ years old) primarily prey on fish and macrobenthos and rarely on planktonic invertebrates. Seasonal changes in diet were also observed in this population. Pelagic organisms such as euphasiids and mesopelagic fishes were the main prey items in the spring, whereas benthic species were the dominant prey item in autumn. Such variability in the type of prey items consumed by Pacific cod may reflect the general feeding characteristics of this species and seasonal changes in the biotic environment. Our observations suggest that large Pacific cod (age $\geq 2+$ ) also consume mesopelagic invertebrates and that small individuals (age 1+) feed on similar items. However, Pacific cod basically shift their feeding habit from small plankton to macrobenthos with growth, and macrobenthic organisms such as large octopi and flatfishes can be prey items only for large cod because of the gape limitation of Pacific cod. The demersal fish such as sand lance and flatfish tended to accumulate radiocesium in their body and are only preyed on by large Pacific cod. The ontogenetic niche shift and species-specific difference in 
radiocesium concentration may result in the size-dependent difference in radiocesium concentrations observed in Pacific cod.

\subsection{Radiocesium Concentration of Prey Items}

A part of the species that occurred in the stomachs of Pacific cod were caught in the trawl surveys. The radiocesium concentrations of them and a part of prey items were measured by same method as the fish samples. The concentrations of the rest organisms were referred from the previous reports, respectively (MAFF 2014; Sohtome et al. 2014).

The radiocesium concentrations were analyzed for 17 species or taxon, which are the main prey items of Pacific cod in Sendai Bay and Tohoku (Fig. 10.8). The

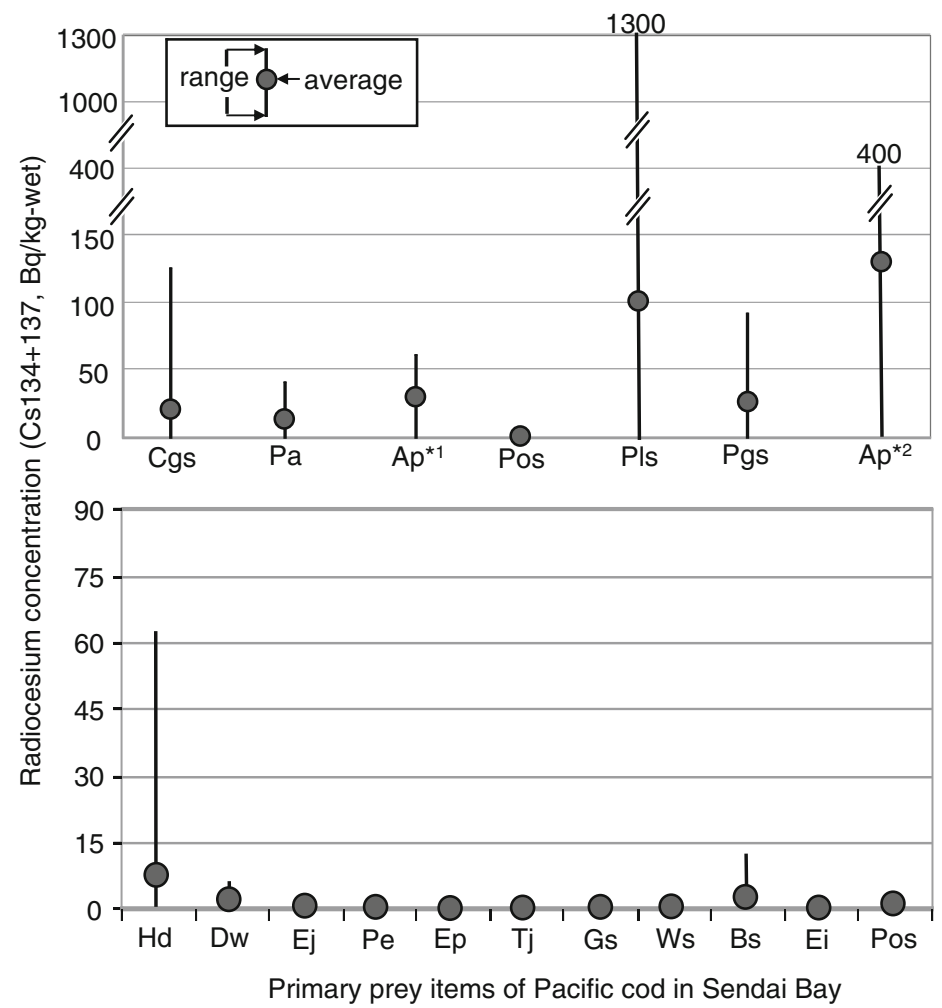

Fig. 10.8 Radiocesium concentrations in the primary prey items of Pacific cod in Sendai Bay (upper) and off Tohoku (lower). Species or taxon are shown by abbreviations: Cgs Crangon spp., Pa Pennahia argentata, Ap Ammodytes personatus, Pos Paroctopus spp., Pls Pleuronectes spp., Pgs Pagurus spp., Hd Hippoglossoides dubius, Dw Diaphus watasei, Ej Engraulis japonicus, Pe Pandalus eous, Ep Euphausia pacifica, Tj Themisto japonica, Gs Gammaridea spp., Ws Watasenia scintillans, Bs Brachyura spp., Ei Erimacrus isenbeckii. The indicators $* 1$ and $* 2$ indicate specimens caught from April 2011 to March 2012 and from April 2012 to December 2012, respectively 
concentration of radiocesium in Crangon spp. and white croaker (Pennahia argentata, Pisces) ranged from below the detection limit (DL) to $126.3 \mathrm{~Bq} / \mathrm{kg}$-wet weight (mean $\pm \mathrm{SD}=19.5 \pm 24.3$ ) and below the DL to $41.0 \mathrm{~Bq} / \mathrm{kg}$-wet (12.5 \pm 16.3 ), respectively. The concentration of radiocesium was higher within 1 year after the accident $(134.5 \pm 102.7)$ than 1 year after the accident $(29.0 \pm 21.8)$ in the sand lance Ammodytes personatus, the dominant prey item of age $\geq 2+$ cod. Although the radiocesium concentrations in all Paraoctopus spp. and hermit crab Pagurus spp. (Anomura) were below the DL or relatively low $(24.4 \pm 24.3)$, high levels were detected in some Pleuronectes spp. specimens (102.5 \pm 169.2$)$. Almost all the prey items consumed on the upper continental slope had levels below the DL, except for the flathead flounder Hippoglossoids dubius $(7.7 \pm 14.7)$ and crabs (Tymolus japonicus, Carcinoplax vestiva: $2.8 \pm 4.9$ ). These results suggest that the concentrations of radiocesium were very low in the prey of Pacific cod (all age groups) off the FNPP at a depth of $250 \mathrm{~m}$. In Sendai Bay, organisms consumed by age 1+ Pacific cod had relatively low radiocesium levels. However, some prey items observed in the stomach of age $\geq 2+$ cod had relatively high radiocesium levels.

As described here, the timing of the migration from offshore to inshore and vice versa was similar between age classes, suggesting that the exposure to radiocesium was similar regardless of age and body size. However, the concentration of radiocesium was always higher in older and larger fish than in younger and smaller fish.

A number of marine organisms, including seaweeds, invertebrates, and fish, were contaminated by the radiocesium released from FNPP. The concentration and rate of decrease varied among species, likely because of differences in their biological characteristics (Wada et al. 2013). The levels of radiocesium were highest soon after the FNNP accident in all taxon (Wada et al. 2013). This pattern suggests that radiocesium contamination of all organisms primarily occurred in the first few months after the accident. Organisms that were distributed near the FNPP accumulated radiocesium from the seawater and prey items. The concentration of radiocesium in Pacific cod was variable, likely dependent on the initial intake of radiocesium, rate of decrease speed of radiocesium, the amount of additional intake of radiocesium from seawater, and the rate of growth (BW) during the first few months. However, additional intake of radiocesium only occurred via prey because radiocesium concentration in seawater was rapidly diluted/transported out of the area within a year, except for that in the port of FNPP (Buesseler et al. 2011; Aoyama et al. 2013; Kaeriyama et al. 2013, 2014); those levels in pelagic fish rapidly decreased (Iwata et al. 2013; Wada et al. 2013), and Pacific cod seldom inhabit and stay in the intertidal zone.

Pacific cod grow very rapidly (Hattori et al. 1992), resulting in dilution of the radiocesium in their body (dilution effect). Age 1+ cod are about $0.5 \mathrm{~kg} \mathrm{BW}$ but grow to $1.5 \mathrm{~kg} \mathrm{BW}$ in 1 year. Similarly, cod that are $1.0 \mathrm{~kg} \mathrm{BW}$ (age 2+) grow to $2.3 \mathrm{~kg} \mathrm{BW}$ in a year. A $0.5-\mathrm{kg} \mathrm{BW}$ individual has a 1.30 times higher dilution effect for radiocesium than does a 1.0-kg BW cod. The ecological half-time of radiocesium was estimated to be 258 and 309 days in the 2010 and the $\leq 2009$ year-classes, respectively. Taking into consideration both the dilution effect and the age-specific decrease in concentrations, the level of radiocesium in the 2010 year-class is 
expected to decrease 1.56 times earlier than in the $\leq 2009$ year-classes. The mean concentration of radiocesium in the $\leq 2009$ year-classes was 1.75 times higher than in the 2010 year-class during the period January 2012 to March 2013. Assuming the initial concentrations were similar between year-classes, the difference between observed values and estimated values (based on dilution and age-specific effects) may be explained by the ontogenetic differences in prey items and their radiocesium concentration.

\subsection{Conclusion}

Large numbers of marine organisms were contaminated by radiocesium following the FNPP accident in March 2011. In some demersal fishes that inhabit the coastal regions, the rate of decrease in tissue radiocesium levels was lower than for other pelagic fishes and invertebrates, suggesting that additional radiocesium was taken up from the benthic ecosystem. This finding delayed the reopening of fisheries in the region. The estimated ecological half-life of radiocesium in Pacific cod was from 258 to 309 days; this value is consistent with values in other demersal fishes caught off Fukushima Prefecture (Wada et al. 2013). The half-life was longer in old and larger individuals than in young and small individuals, probably a result of differences in metabolic rate and growth rates between age and body size classes (Doi et al. 2012). Radiocesium concentrations decreased to low levels soon after the accident in seawater and prey items (Buesseler et al. 2011; Aoyama et al. 2013) and have continued to decease in the period up to 2014 (Sohtome et al. 2014). Thus, the potential for intake of radiocesium from the benthic ecosystem is very low in and after 2014. Additionally, radiocesium was rarely detected in the 2011 year-class. Pacific cod hatch during January to February in Sendai Bay (Narimatsu et al., unpublished data) and live a pelagic life for 3-4 months in the coastal zone. Some individuals of the 2011 year-class took in radiocesium via seawater and diet. However, the concentration of radiocesium in their body was diluted by growth, and the fish were only exposed to very low levels of radiocesium after settlement to benthic life. The Pacific cod of the following year-classes had already recruited into the ecosystem of the upper continental slope and were commercially caught in the Tohoku region. This population is primarily composed of young fish, and the generation cycle alters quickly (Narimatsu et al. 2010). We observed a decrease in radiocesium concentrations in the 2010 and $\geq 2009$ year classes and an increase in the proportion of individuals born after the accident at the Nuclear Power Plant. Both these factors reduce the radiocesium concentrations at the population level and suggest the risk of restarting fisheries is minimal.

Acknowledgments We are grateful to the crews of R/Vs Wakataka maru and Dai-nana Kaiyo maru for assistance in obtaining samples. We also thank Drs. T. Wada and M. Ito for comments on the manuscript, and the staff of Hachinohe Laboratory, Tohoku National Fisheries Research Institute, for help in preparing samples. This work was financially supported by the Fisheries Agency, Japan. 
Open Access This chapter is distributed under the terms of the Creative Commons Attribution Noncommercial License, which permits any noncommercial use, distribution, and reproduction in any medium, provided the original author(s) and source are credited.

\section{References}

Aoyama M, Uematsu M, Tsumune D, Hamajima Y (2013) Surface pathway of radioactive plume of TEPCO Fukushima NPP1 released ${ }^{134} \mathrm{Cs}$ and ${ }^{137} \mathrm{Cs}$. Biogeosci Discuss 10:265-285

Buesseler KO, Aoyama M, Fukasawa M (2011) Impacts of the Fukushima nuclear power plants on marine radioactivity. Environ Sci Technol 45:9931-9935

Buesseler KO (2012) Fishing for answers off Fukushima. Science 388:480-482

Doi H, Takahara T, Tanaka K (2012) Trophic position and metabolic rate predict the long-term decay process of radiocesium in fish: a meta-analysis. PLoS ONE 7:e29295. doi:10. 1371/ journal.pone.0029295

Fujita T, Kitagawa D, Okuyama Y, Ishito Y, Inada T, Jin Y (1995) Diets of the demersal fishes on the shelf off Iwate, northern Japan. Mar Biol 123:219-233

Hashimoto R (1974) Investigation of feeding habits and variation of inhabiting depths with cod (Gadus macrocephalus) distributed on the northeastern fishing ground in Japan. Bull Tohoku Reg Fish Res Lab 33:51-67

Hattori T, Narimatsu Y, Ito M, Ueda Y, Kitagawa D (2008) Annual changes in distribution depths of bighand thornyhead Sebastolobus macrochir off the Pacific coast of northern Honshu Japan. Fish Sci 74:594-602

Hattori T, Sakurai Y, Shimazaki K (1992) Age determination by sectioning of otoliths and growth pattern of Pacific cod. Nippon Suisan Gakkaishi 58:1203-1210 (In Japanese with English abstract)

Ito S, Uehara K, Miyao T, Miyake H, Yasuda I, Watanabe T, Shimizu Y (2004) Characteristics of SSH anomaly based on TOPEX/POSEIDON altimetry and in situ measured velocity and transport of Oyashio on OICE. J Oceanogr 60:425-438

Iwata K, Tagami K, Uchida S (2013) Ecological half-lives of radiocesium in 16 species in marine biota after the TEPCO's Fukushima Daiichi Nuclear Power Plant accident. Environ Sci Technol 47:7696-7703

Kaeriyama H, Ambe D, Shimizu Y, Fujimoto K, Ono T, Yonezaki S, Kato Y, Matsunaga H, Minami H, Nakatsuka S, Watanabe T (2013) Direct observation of ${ }^{134} \mathrm{Cs}$ and ${ }^{137} \mathrm{Cs}$ in the western and central North Pacific after the Fukushima Dai-ichi Nuclear Power Plant accident. Biogeosciences 10:4287-7295

Kaeriyama H, Shimizu Y, Ambe D, Masujima M, Shigenobu Y, Fujimoto K, Ono T, Nishiuchi K, Taneda T, Kurogi H, Setou T, Sugisaki H, Ichikawa T, Hidaka K, Hiroe Y, Kusaka A, Kodama T, Kuriyama M, Morita H, Nakata K, Morinaga K, Morita T, Watanabe T (2014) Southwest intrusion of ${ }^{134} \mathrm{Cs}$ and ${ }^{137} \mathrm{Cs}$ derived from the Fukushima Dai-ichi Nuclear Power Plant accident in the western North Pacific. Environ Sci Technol 48:3120-3127

Kitagawa D, Hattori T, Narimatsu Y (2002) Monitoring on the demersal fish resources in the Tohoku area. Kaiyo Mon 34:793-798 (in Japanese)

MAFF (Japan Ministry of Agriculture, Forestry and Fisheries) (2014) Results of the inspection on radioactivity materials in fisheries products. http://www.jfa.maff.go.jp/e/inspection/index. html. Accesssed 31 July 2014

Morita T, Yoshida K (2005) Effective ecological half-lives of Cs-137 for fishes controlled by their surrounding sea-waters. Radioprotection 40(Suppl, 1):S635-S640

Narimatsu Y, Ito M, Hattori T, Inagawa R (2014) Stock assessment and evaluation for the threadfin hakeling stock of the north Pacific, Japan (fiscal year 2013). In: Marine fisheries stock assessment and evaluation for Japanese waters (fiscal year 2013/2014), Fishries Agency and Fisheries Research Agency of Japan, pp 851-867 
Narimatsu Y, Ueda Y, Okuda T, Hattori T, Fujiwara K, Ito M (2010) The effect of temporal changes in life-history traits on reproductive potential in an exploited population of Pacific cod, Gadus macrocephalus. ICES J Mar Sci 67:1659-1666

Sohtome T, Wada T, Mizuno T, Nemoto Y, Igarashi S, Nishimune A, Aono T, Ito Y, Kanda J, Ishimaru T (2014) Radiological impact of TEPCO's Fukushima Dai-ichi Nuclear Power Plant accident on invertebrates in the coastal benthic food web. J Environ Radioact 138:106-115

Tsumune D, Tsubono T, Aoyama M, Hirose K (2012) Distribution of oceanic 137Cs from the Fukushima dai-ichi Nuclear Power Plant simulated numerically by a regional ocean model. J Environ Radioact 111:100-108

Wada T, Nemoto Y, Shimamura S, Fujita T, Mizuno T, Sohtome T, Kamiyama K, Morita T, Igarashi S (2013) Effects of the nuclear disaster on marine products in Fukushima. J Environ Radioact 124:246-254

Yamamura O (1994) Ecological study on demersal fish community off Sendai Bay, northern Japan, with special reference to niche dynamics among dominant fishes. Doctoral dissertation, Hokkaido University 